\title{
Impact of alternate furrow irrigation with different irrigation intervals on yield, water use efficiency, and economic return of corn
}

\author{
Awad Abd El-Halim ${ }^{1}$
}

\begin{abstract}
Alternate furrow irrigation with proper irrigation intervals could save irrigation water and result in high grain yield with low irrigation costs in arid areas. Two field experiments were conducted in the Middle Nile Delta area of Egypt during the 2010 and 2011 seasons to investigate the impact of alternate furrow irrigation with 7-d ( $\left.\mathrm{AFI}_{7}\right)$ and $14-\mathrm{d}$ intervals $\left(\mathrm{AFI}_{14}\right)$ on yield, crop water use efficiency, irrigation water productivity, and economic return of corn (Zea mays L.) as compared with every-furrow irrigation (EFI, conventional method with 14-d interval). Results indicated that grain yield increased under the $\mathrm{AFI}_{7}$ treatment, whereas it tended to decrease under $\mathrm{AFI}_{14}$ as compared with EFI. Irrigation water saving in the $\mathrm{AFI}_{7}$ and $\mathrm{AFI}_{14}$ treatments was approximately $7 \%$ and $17 \%$, respectively, as compared to the EFI treatment. The $\mathrm{AFI}_{14}$ and $\mathrm{AFI}_{7}$ treatments improved both crop water use efficiency and irrigation water productivity as compared with EFI. Results also indicated that the $\mathrm{AFI}_{7}$ treatment did not only increase grain yield, but also increased the benefit-cost ratio, net return, and irrigation water saving. Therefore, if low cost water is available and excess water delivery to the field does not require any additional expense, then the $\mathrm{AFI}_{7}$ treatment will essentially be the best choice under the study area conditions.
\end{abstract}

Key words: Corn, alternate furrow irrigation, water productivity, crop water use efficiency, water saving.

\section{INTRODUCTION}

Water resources in Egypt are limited and restrict crop production in the newly reclaimed lands because of current intensive agricultural production. Agriculture in Egypt relies heavily on irrigation. The agricultural sector consumes more than $84 \%$ of available water resources (El-Beltagy and Abo-Hadeed, 2008).

Corn (Zea mays L.) is one of the major cereal crops in Egypt. It is the most important foodstuff for the indigenous population living in rural areas. Thus, it can be considered as the second food crop after wheat (Triticum aestivum L.). Corn grain production in Egypt is approximately 12 million tons (USDA, 2011).

Alternate furrow irrigation (AFI) is considered to be one of the most effective tools to minimize water application and irrigation costs and produce a higher crop yield. The AFI method is a way to save irrigation water, improve irrigation efficiency, and increase corn yield (Shayannejad and Moharreri, 2009; Nasri et al., 2010; Rafiee and Shakarami, 2010; Kashiani et al., 2011). Sepaskhah and Khajehabdollahi (2005) found that corn grain yield in a fine-textured soil with a deep water table and AFI at 7-d intervals was statistically lower than everyfurrow irrigation (EFI) at 10-d intervals. Shorter irrigation

${ }^{1}$ Tanta University, Faculty of Agriculture, Kafr El-Sheikh road, Seberbay, Tanta, Egypt.

"Corresponding author (halim.ismail@agr.tanta.edu.eg).

Received: 6 December 2012.

Accepted: 29 April 2013.

doi:10.4067/S0718-58392013000200014. intervals (4-d) in AFI can ease water stress and not reduce yield as compared with EFI at 7-d intervals even though water application was reduced. In general, when water was insufficient for full irrigation relative corn grain yield (yield per unit water applied) under AFI was higher than EFI. In addition, Li et al. (2007) found that alternate partial root-zone and fixed partial root-zone irrigation techniques led to a higher reduction of transpiration than photosynthesis and thus increased corn leaf water use efficiency (WUE). In Egypt, Abdel-Maksoud et al. (2002) found that AFI at 14-d intervals seemed to not significantly decrease yield, whereas yield increased under AFI at 7-d intervals as compared with the EFI method. They also found that WUE values improved under AFI as compared with the EFI method. The economic and environmental benefits of using the AFI method are higher than all other irrigation methods because less water is applied and the economic return is higher (Nelson and Al-Kaisi, 2011).

The objective of this research study was to investigate the effects of alternate furrow irrigation with two different irrigation intervals (7-d and 14-d intervals) on corn yield, WUE, irrigation water productivity, and economic return as compared with EFI (conventional method).

\section{MATERIALS AND METHODS}

\section{Description of the study area}

The field experiment was conducted on a private farm $\left(30^{\circ} 79^{\prime} \mathrm{N}, 30^{\circ} 9^{\prime} \mathrm{E}, 22 \mathrm{~m}\right.$ a.s.l.) $15 \mathrm{~km}$ north of Tanta, Al-Gharbiya governorate, Egypt, during the 2010 and 2011 corn-growing seasons. The soil of the study area is 
characterized by a clay texture with a water table depth greater than $3 \mathrm{~m}$. It was classified as a Vertic Torrifluvents (El-Baroudy, 2011). Some hydrophysical characteristics of the soil used in the experiment were outlined by Carter and Gregorich (2008) and are shown in Table 1.

The climate is characterized by a cool winter with an approximate mean air temperature of $15.6^{\circ} \mathrm{C}$. Summer is hot with no rain and an approximate mean air temperature of $25.6^{\circ} \mathrm{C}$ during June, July, and August; the mean relative humidity is $65 \%$ during day-time for these months. Pan evaporation reaches approximately $8 \mathrm{~mm} \mathrm{~d}^{-1}$ in June.

\section{Treatments and experimental design}

Irrigation treatments were: 1) Conventional irrigation method (EFI), every furrow was irrigated at 14-d intervals; 2) Alternate furrow irrigation $\left(\mathrm{AFI}_{14}\right)$ : only selective watering of every other furrow, that is, each bed receives water only on one side and alternating sides/ furrow at 14-d intervals and odd furrows $(1,3,5$, etc.) are irrigated first followed by even furrows $(2,4,6$, etc.); and 3) Alternate furrow irrigation $\left(\mathrm{AFI}_{7}\right)$ : similar to $\mathrm{AFI}_{14}$ but watering at 7-d intervals.

The adopted treatments were assessed with arandomized complete block design (RCBD) with three replicates. The experimental plot size was $45.5 \mathrm{~m}^{2}(9.1 \mathrm{~m}$ wide $\times 5.0 \mathrm{~m}$ long). Each treatment included 15 furrows and 14 planting ridges (rows). Furrow spacing was 0.65 $\mathrm{m}$. The experimental plots were separated by earth banks (1.3 $\mathrm{m}$ wide and $0.5 \mathrm{~m}$ high).

\section{Agronomic practices}

Corn seeds (TWC 324) were planted on 25 May in the 2010 and 2011 growing seasons at the rate of $36 \mathrm{~kg} \mathrm{ha}^{-1}$. Two seeds were planted per hole with a plant spacing of 0.25 $\mathrm{m}$. All plots were irrigated immediately after planting (planting irrigation). Because of the clay texture of the experimental field, a complementary irrigation was applied on the 10th day after planting (DAP) to ensure complete seed germination (first pre-treatment irrigation). Prior to the second pre-treatment irrigation (35 DAP), plants were thinned to one per stand for a population of 280 plants per plot and a projection of approximately 61539 plants $\mathrm{ha}^{-1}$. All furrows were irrigated during pre-treatment irrigation. Nitrogen fertilizer as ammonium nitrate (396 $\mathrm{kg} \mathrm{ha}^{-1}, 33.5 \% \mathrm{~N}$ ) and $\mathrm{K}$ fertilizer as potassium sulfate (120 kg ha-1 $48 \% \mathrm{KO}_{2}$ ) were applied with the second pretreatment irrigation. Phosphorus fertilizer as single super phosphate $\left(480 \mathrm{~kg} \mathrm{ha}^{-1}, 15.5 \% \quad \mathrm{P}_{2} \mathrm{O}_{5}\right)$ was incorporated into the soil during land preparation. All other agricultural operations, including pesticide and hand weeding, were applied uniformly and simultaneously for all treatments. Experimental treatments were implemented after the second pre-treatment irrigation in both seasons. Corn was harvested at 123 DAP by cutting the aboveground biomass and left for further drying before removing the cobs from the stalks. The crop was then threshed and grain yield (at $15 \%$ moisture content) was measured.

\section{Irrigation management}

Irrigation water was conveyed to the experimental plots through an open channel using a circular orifice $(15 \mathrm{~cm}$ diameter) to measure total applied water (James, 1988).

The amount of water for each application was added until reaching $95 \%$ of run length on the average of all furrows. This is in accordance with local farmer practice in the area. Time is then recorded with a stopwatch to estimate the amount of water applied to each plot. Furrows subjected to irrigation were open-ended; however, water does not exceed the edge of the plot because it flows through the parallel furrows, whereas other furrows not subjected to irrigation were closed-ended. The water in the channel was controlled to maintain a constant head to provide an adequate inflow rate during irrigation events with a fixed bar. The end of the channel was connected to a drainage ditch to release excess water.

\section{Depth of applied water}

The depth of applied water was calculated using the following formula:

$$
\mathrm{d}=\mathrm{Qt} \times 1000 / \mathrm{A}
$$

where $d$ is depth (mm); $Q$ is orifice discharge $\left(\mathrm{m}^{3} \mathrm{~min}^{-1}\right) ; t$ is time ( $\mathrm{min}$ ), and $A$ is plot area $\left(\mathrm{m}^{2}\right)$.

The depth of applied water varied according to the time for each irrigation treatment. Total depth of applied water (Wa) was the sum of the amounts of water added at each irrigation event during the entire growing season.

Table 1. Soil hydro-physical characteristics in the experimental field.

\begin{tabular}{|c|c|c|c|c|c|c|}
\hline \multirow[b]{3}{*}{ Characteristics } & \multicolumn{6}{|c|}{ Soil depth $(\mathrm{cm})$} \\
\hline & \multicolumn{3}{|c|}{2010 Season } & \multicolumn{3}{|c|}{2011 Season } \\
\hline & $0-30$ & $30-60$ & $60-90$ & $0-30$ & $30-60$ & $60-90$ \\
\hline Sand, \% & 24.36 & 21.86 & 25.10 & 22.9 & 19.6 & 23.10 \\
\hline Silt, \% & 26.58 & 27.75 & 40.10 & 31.88 & 32.25 & 40.20 \\
\hline Clay, \% & 49.06 & 50.39 & 34.80 & 47.22 & 48.15 & 36.70 \\
\hline Soil texture & Clay & Clay & Clay Loam & Clay & Clay & Clay Loam \\
\hline Bulk density, $\mathrm{g} \mathrm{cm}^{-3}$ & 1.26 & 1.40 & 1.49 & 1.24 & 1.38 & 1.47 \\
\hline $\mathrm{FC}, \% \mathrm{ww}$ & 41.60 & 38.60 & 38.20 & 41.30 & 38.60 & 38.00 \\
\hline PWP, \% ww & 21.78 & 20.84 & 20.51 & 21.81 & 20.54 & 20.10 \\
\hline AW, mm depth & 74.92 & 74.59 & 79.07 & 72.50 & 74.77 & 78.94 \\
\hline
\end{tabular}

FC: moisture content at field capacity; PWP: moisture content at permanent wilting point; AW: available water content; ww:wet weight. 


\section{Consumptive water use (CWU)}

Soil samples were taken with a screw auger at planting, before each irrigation event, $2 \mathrm{~d}$ after each irrigation event, and at harvest. Samples were taken at three depths: 0-30, 30-60 and 60-90 $\mathrm{cm}$ from both the ridge and bottom of the furrows. Samples were used to measure volumetric soil-water content in the root zone by the gravimetric method, based on the conventional oven-dry weight and multiplied by bulk density.

The quantities of consumptive water use (CWU) were calculated using the following equation (James, 1988):

$$
\mathrm{CWU}=\left(\theta_{2}-\theta_{1}\right) \times \mathrm{Bd} \times \mathrm{ERZ}
$$

where CWU is water consumptive use $(\mathrm{mm}), \theta_{2}$ is percentage of soil moisture after irrigation, $\theta_{1}$ is percentage of soil moisture before the subsequent irrigation, $\mathrm{Bd}$ is bulk density $\left(\mathrm{g} \mathrm{cm}^{-3}\right)$, and ERZ is the effective root zone.

Water use efficiency (WUE crop )

Crop water use efficiency was determined as the ratio of grain yield $(\mathrm{kg})$ and the cubic meter of water consumed by the crop (CWU) during the growing season and is expressed as follows (Ali et al., 2007):

$$
\mathrm{WUE}_{\text {crop }}=\mathrm{GY} / \mathrm{CWU}
$$

where $\mathrm{WUE}_{\text {crop }}$ is crop water use efficiency $\left(\mathrm{kg} \mathrm{m}^{-3}\right)$; GY is grain yield $\left(\mathrm{kg} \mathrm{ha}^{-1}\right)$, and CWU is consumptive water use $\left(\mathrm{m}^{3} \mathrm{ha}^{-1}\right)$.

\section{Water productivity (WP)}

Water productivity was determined by dividing grain yield by total applied irrigation water and is expressed as follows (Ali et al., 2007):

$$
\mathrm{WP}=\mathrm{GY} / \mathrm{W}
$$

where GY is grain yield $\left(\mathrm{kg} \mathrm{ha}^{-1}\right)$ and Wa is irrigation applied water $\left(\mathrm{m}^{3} \mathrm{ha}^{-1}\right)$.

\section{Benefit-cost ratio (BCR) and net return (NR)}

The total cost mainly includes operating and variable costs. Operating costs (labor, land preparation, seeds, fertilizers, and chemicals) were based on the planted area. Therefore, the operating costs of the two AFI treatments were the same as the conventional EFI treatment and totaled 2500 Egyptian pounds (EGP) per hectare (Exchange rate: $1 \mathrm{EGP} \approx \mathrm{US} \$ 0.17$ in 2011). Variable costs depended on the number of irrigation events and water unit price. The indigenous irrigation farmers in the study area do not pay for water for their farms. Therefore, they only bear the costs of labor to irrigate (estimated 250 EGP ha $^{-1}$ based on the irrigated area and the man-day labor cost of $50 \mathrm{EGP}$ ), as well as the price of fuel to run a pump to withdraw water from irrigation canals. The water unit price was estimated to be $0.25 \mathrm{EGP} \mathrm{m}^{-3}$. Total water cost for each season was calculated by multiplying the water unit price by the total amount of irrigation water required for the corn crop. Gross revenue has been calculated by multiplying total yield in $\mathrm{kg} \mathrm{ha}^{-1}$ and corn market price per kilogram. The farm-gate price for corn grain in this study was $1.6 \mathrm{EGP} \mathrm{kg}^{-1}$ (local price). Net return (NR) and benefit-cost ratio (BCR) due to irrigation were calculated according to $\mathrm{Li}$ et al., 2005 as follows:

$$
\begin{gathered}
\mathrm{NR}=\text { Gross revenue }- \text { Total costs } \\
\text { BCR }=\text { NR/Total costs }
\end{gathered}
$$

\section{Statistical analysis}

Statistical ANOVA was performed with MSTATC ${ }^{\mathrm{TM}}$ version 2.0. The significant differences between means were tested by Duncan's Multiple Range Test (DMRT) at $5 \%$ probability level.

\section{RESULTS AND DISSCUSION}

\section{Applied irrigation water (Wa)}

The number of irrigation events and amount of applied water (Wa) for each treatment are shown in Table 2. The $\mathrm{AFI}_{7}$ treatment was more frequent (11 irrigation events) than $\mathrm{EFI}$ and $\mathrm{AFI}_{14}$ (seven irrigation events). The seasonal amount of Wa was the mean of the two seasons and amounted to $531.5 \mathrm{~mm}\left(5315 \mathrm{~m}^{3} \mathrm{ha}^{-1}\right)$, $499.5 \mathrm{~mm}\left(4995 \mathrm{~m}^{3} \mathrm{ha}^{-1}\right)$, and $440 \mathrm{~mm}\left(4400 \mathrm{~m}^{3} \mathrm{ha}^{-1}\right)$ for $\mathrm{EFI}, \mathrm{AFI}_{7}$, and $\mathrm{AFI}_{14}$, respectively. This indicates that the $\mathrm{AFI}_{14}$ and $\mathrm{AFI}_{7}$ alternate furrow irrigation treatments saved water by approximately $17 \%$ and $6 \%$ (two-season means), respectively, as compared to conventional EFI. Alternate-furrow irrigation at 7-d intervals $\left(\mathrm{AFI}_{7}\right)$ applied more water than $\mathrm{AFI}_{14}$ (12\%), while EFI applied $13 \%$ more water than the mean of the two alternative furrow treatments. Regardless of irrigation intervals, the lowest amount of applied water (Wa) under AFI treatments as compared with EFI might be due to the great reduction of wetted surface in AFI; almost half of the soil surface is wetted in AFI as compared with EFI. This result supports the outcome obtained by Graterol et al. (1993), who found that AFI methods can supply water in a way that greatly reduces the amount of wetted surface, which leads to less

\begin{tabular}{|c|c|c|c|c|c|c|}
\hline \multirow{3}{*}{$\begin{array}{l}\text { Treatments }{ }^{1} \\
\text { Irrigation } \\
\text { event }\end{array}$} & \multicolumn{2}{|c|}{ EFI } & \multicolumn{2}{|c|}{$\frac{\mathrm{AFI}_{7}}{\text { Season }}$} & \multicolumn{2}{|c|}{$\mathrm{AFI}_{14}$} \\
\hline & 2010 & 2011 & 2010 & 2011 & 2010 & 2011 \\
\hline & \multicolumn{6}{|c|}{ Depth of applied water $(\mathrm{mm})$} \\
\hline First & 115 & 120 & 118 & 122 & 116 & 121 \\
\hline Second & 62 & 58 & 61 & 59 & 60 & 58 \\
\hline Third & 81 & 80 & 79 & 77 & 82 & 79 \\
\hline Fourth & 68 & 72 & 33 & 34 & 53 & 59 \\
\hline Fifth & 71 & 70 & 32 & 34 & 55 & 48 \\
\hline Sixth & 72 & 71 & 30 & 32 & 36 & 44 \\
\hline Seventh & 60 & 63 & 30 & 32 & 36 & 33 \\
\hline Eighth & - & - & 29 & 30 & - & - \\
\hline Nineth & - & - & 28 & 29 & - & - \\
\hline Tenth & - & - & 28 & 28 & - & - \\
\hline Eleventh & - & - & 27 & 27 & - & - \\
\hline Total & 529 & 534 & 495 & 504 & 438 & 442 \\
\hline
\end{tabular}
evapotranspiration and less deep percolation. The amount

Table 2. Number of irrigation events and depth of applied water for each irrigation event under different irrigation treatments during the 2010 and 2011 growing seasons.

${ }^{1}$ EFI: Every-furrow irrigation; $\mathrm{AFI}_{7}$ : alternate furrow irrigation with 7-d intervals; $\mathrm{AFI}_{14}$ : alternate furrow irrigation with 14-d intervals. 
of Wa with AFI at 7-d intervals was greater than at 14-d intervals. This can be attributed to more frequent irrigation under the $\mathrm{AFI}_{7}$ treatment (Abdel-Maksoud et al., 2002). Reduced irrigation water due to the alternate-furrow technique was reported by El-Sharkawy et al. (2006), Sepaskhah and Parand (2006), Sepaskhah and Ghasemi (2008), Shayannejad and Moharreri (2009) for potato; Sepaskhah and Hosseini (2008) for wheat; Ibrahim and Emara (2010) for sugar beet; Nelson and Al-Kaisi (2011).

\section{Consumptive water use (CWU)}

Consumptive water use (CWU) was significantly affected by the irrigation treatments and had the same trend in both seasons (Table 3). The highest CWU at 476 and $480 \mathrm{~mm}$ were recorded for EFI followed by 445 and $454 \mathrm{~mm}$ for $\mathrm{AFI}_{7}$, while the lowest values of 394 and $398 \mathrm{~mm}$ were obtained under $\mathrm{AFI}_{14}$ in the first and second season, respectively. These results indicate that $\mathrm{AFI}_{7}$ and $\mathrm{AFI}_{14}$ decreased CWU by approximately $6 \%$ and $17 \%$ (twoseason mean), respectively, as compared with conventional EFI. The CWU value for $\mathrm{AFI}_{14}$ was lower than for $\mathrm{AFI}_{7}$, which may be due to the fact that corn plants grown under $\mathrm{AFI}_{14}$ treatment conditions were subjected to water stress resulting from less frequent irrigation and lower amount of applied water. As shown in Figure 1, the control treatment (EFI) never had water stress since the soil water content values remained above or near field capacity during the whole season, whereas soil water content values remained near the wilting point with severe implications for corn growth in the $\mathrm{AFI}_{14}$ treatment. Small differences in soil water content were found between $\mathrm{EFI}$ and $\mathrm{AFI}_{7}$ and soil moisture content values for $\mathrm{AFI}_{7}$ were near field capacity. The high water content for $\mathrm{AFI}_{7}$ provides a buffer for the short drought episodes during the growing season. As a consequence, $\mathrm{CWU}$ for $\mathrm{AFI}_{7}$ was near $\mathrm{CWU}$ for $\mathrm{EFI}$. This

Table 3. Grain yield and corn-water relationship parameters under different irrigation treatments.

\begin{tabular}{|c|c|c|c|c|c|c|}
\hline \multirow[b]{2}{*}{ Treatments $^{1}$} & \multicolumn{6}{|c|}{ Corn-water relationship parameters ${ }^{2}$} \\
\hline & $\overline{\mathrm{GY}^{3}}$ & $\Delta \mathrm{GY}$ & CWU & $\Delta \mathrm{CWU}$ & WUE $_{\text {crop }}$ & WP \\
\hline & $\mathrm{t} \mathrm{ha}^{-1}$ & $\%$ & $\mathrm{~mm}$ & $\%$ & $-\mathrm{kg} \mathrm{m}^{-}$ & \\
\hline \multicolumn{7}{|l|}{ Season, 2010} \\
\hline EFI & $5.66 \mathrm{~b}$ & - & $476 \mathrm{a}$ & - & $1.19 \mathrm{c}$ & $1.07 \mathrm{c}$ \\
\hline $\mathrm{AFI}_{7}$ & $6.14 \mathrm{a}$ & +8.4 & $445 b$ & 6.5 & $1.38 \mathrm{a}$ & $1.24 \mathrm{a}$ \\
\hline $\mathrm{AFI}_{14}$ & $5.25 \mathrm{c}$ & -7.7 & $394 \mathrm{c}$ & 17.2 & $1.33 b$ & $1.20 \mathrm{~b}$ \\
\hline $\mathrm{LSD}_{0.05}$ & 0.16 & - & 0.023 & - & 0.023 & 0.023 \\
\hline \multicolumn{7}{|l|}{ Season, 2011} \\
\hline EFI & $5.94 b$ & - & $480 \mathrm{a}$ & - & $1.24 \mathrm{c}$ & $1.11 \mathrm{~b}$ \\
\hline $\mathrm{AFI}_{7}$ & $6.49 \mathrm{a}$ & +9.3 & $454 b$ & 5.4 & $1.43 \mathrm{a}$ & $1.29 \mathrm{a}$ \\
\hline $\mathrm{AFI}_{14}$ & $5.54 \mathrm{c}$ & -6.7 & $398 \mathrm{c}$ & 17 & $1.39 \mathrm{~b}$ & $1.26 \mathrm{a}$ \\
\hline $\mathrm{LSD}_{0.05}$ & 0.278 & - & 0.023 & - & 0.072 & 0.072 \\
\hline
\end{tabular}

${ }^{1} \mathrm{EFI}$ : Every-furrow irrigation; $\mathrm{AFI}_{7}$ : alternate furrow irrigation with 7-d intervals; and $\mathrm{AFI}_{14}$ : alternate furrow irrigation with 14-d intervals; LSD: least significant difference at 0.05 significance level.

${ }^{2} \mathrm{GY}$ : Grain yield, $\Delta \mathrm{GY}$ : grain yield increase (+) or loss (-) percentage with regards to EFI; Wa: applied irrigation water, WS: water saving, WP: irrigation water productivity, CWU: consumptive water use, $\triangle \mathrm{CWU}$ : percentage decrease of consumptive water usewith regards to EFI, and WUE $\mathrm{W}_{\text {crop }}$ : crop water use efficiency.

${ }^{3}$ Grain yields with the same letter are not significantly different $(\mathrm{P}<0.05)$.

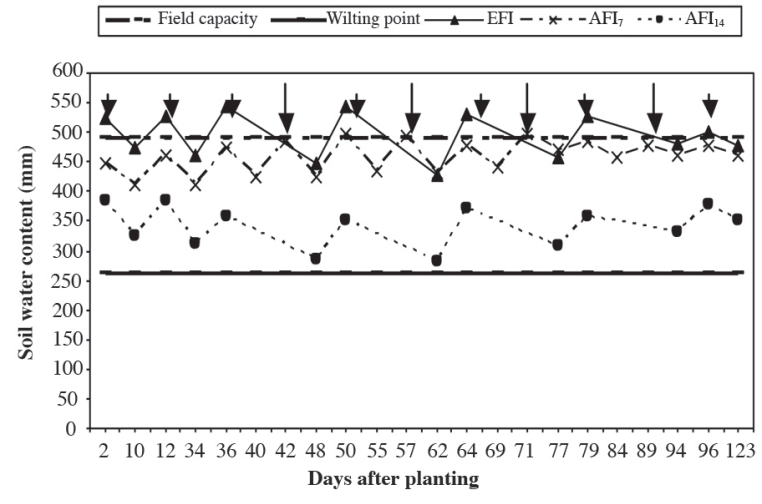

Figure 1. Mean soil water content $(\mathrm{mm})$ at $0-90 \mathrm{~cm}$ depth for everyfurrow irrigation (EFI), alternate furrow irrigation at 7-d intervals $\left(\mathrm{AFI}_{7}\right)$, and alternate furrow irrigation at 14-d intervals $\left(\mathrm{AFI}_{14}\right)$ for two corn-growing seasons (2010 and 2011). Arrows indicate irrigation events.

finding points in the same direction with results obtained by Ibrahim and Emara (2010) for sugar beet.

\section{Grain yield (GY)}

Grain yield (GY) was significantly affected by the irrigation treatments and had the same trend in both seasons (Table 3). The highest GY was in the $\mathrm{AFI}_{7}$ treatment with 6.14 and $6.49 \mathrm{t} \mathrm{ha}^{-1}$, whereas $\mathrm{AFI}_{14}$ exhibited the lowest GY with 5.25 and $5.54 \mathrm{t} \mathrm{ha}^{-1}$ for the first and second seasons, respectively (Table 3 ). Grain yield for EFI (conventional treatment) was higher than for $\mathrm{AFI}_{14}$ with $0.40 \mathrm{t} \mathrm{ha}^{-1}$ in both seasons. When comparing EFI and $\mathrm{AFI}_{7}$, the latter increased GY by approximately 0.48 and $0.55 \mathrm{t} \mathrm{ha}^{-1}$ in the first and second seasons, respectively. The most important result is that $\mathrm{GY}$ for $\mathrm{AFI}_{7}$ was higher than for EFI in spite of the fact that they had almost equal applied irrigation water (Wa). On the other hand, data in both years showed that if $\mathrm{AFI}_{14}$ was used, acceptable GY reduction was observed $\left(0.4 \mathrm{t} \mathrm{ha}^{-1}\right)$ with the lowest amount of Wa (440 mm) in comparison with conventional irrigation (EFI) with high Wa $(532 \mathrm{~mm})$. Shifting irrigation practice from conventional irrigation (EFI) to alternate furrow at 7 -d intervals increased corn yield by approximately $8.9 \%\left(0.5 \mathrm{t} \mathrm{ha}^{-1}\right)$ (two-season mean). The substantial GY decrease in the $\mathrm{AFI}_{14}$ treatment may be due to the small amount of applied irrigation water, which did not match full corn water requirements, caused water stress, and consequently reduced crop yield. This finding is similar to results obtained by Sepaskhah and Khajehabdollahi (2005) and Sepaskhah and Ghasemi (2008) for grain sorghum. On the other hand, AFI with more frequent events at 7-d intervals $\left(\mathrm{AFI}_{7}\right)$ proved to be superior by increasing GY by $8.9 \%$ more than EFI based on a two-season mean. This may be attributed to the better availability of soil moisture during the irrigation cycle for $\mathrm{AFI}_{7}$ (Figure 1), which enhanced water and nutrient uptake and doubtless reflected on final GY. This result confirms the results found by Abdel-Maksoud et al. (2002), Sepaskhah and Khajehabdollahi (2005), 
Sepaskhah and Parand (2006), Sepaskhah and Ghasemi (2008) for grain sorghum; Nasri et al. (2010).

\section{Crop water use efficiency $\left(\mathrm{WUE}_{\text {crop }}\right)$ and irrigation water productivity (WP)}

Crop water efficiency ( $\mathrm{WUE}_{\text {crop }}$ ) for alternate furrow irrigation substantially increased as compared with conventional furrow irrigation (3). The highest $\mathrm{WUE}_{\text {crop }}$ values were 1.38 and $1.43 \mathrm{~kg} \mathrm{~m}^{-3}$ recorded for $\mathrm{AFI}_{7}$, followed by 1.33 and $1.39 \mathrm{~kg} \mathrm{~m}^{-3}$ for $\mathrm{AFI}_{14}$ in the first and second seasons, respectively, whereas the lowest WUE $_{\text {crop }}$ value was 1.19 and $1.24 \mathrm{~kg} \mathrm{~m}^{-3}$ recorded for the EFI treatment in both seasons. These results indicate that both $\mathrm{AFI}_{7}$ and $\mathrm{AFI}_{14}$ achieved high $\mathrm{WUE}_{\text {crop }}$ values as compared with EFI. This could be due to the high yield obtained with $\mathrm{AFI}_{7}$ and lower CWU obtained with $\mathrm{AFI}_{14}$. This result confirms results found by Abdel-Maksoud et al. (2002) and Tavakoli and Oweis (2004) for wheat and Webber et al. (2006) for common green gram bean production.

Irrigation water productivity (WP) was significantly affected by the irrigation treatments. The highest WP values were 1.24 and $1.29 \mathrm{~kg} \mathrm{~m}^{-3}$ recorded for the $\mathrm{AFI}_{7}$ treatment followed by 1.20 and $1.26 \mathrm{~kg} \mathrm{~m}^{-3}$ obtained for $\mathrm{AFI}_{14}$, whereas the lowest values reached 1.07 and 1.11 $\mathrm{kg} \mathrm{m}^{-3}$ for EFI in the first and second seasons, respectively (Table 3). There were no significant statistical differences recorded for WP between $\mathrm{AFI}_{7}$ and $\mathrm{AFI}_{14}$ in the second season, but they were significantly different from the EFI treatment.

These results indicated that AFI is appropriate to increase WP and $\mathrm{WUE}_{\text {crop }}$ because they allow applying less irrigation water for corn production. The high WP values for AFI could be due to the small amount of applied water for AFI as compared with the EFI treatment. Sepaskhah and Hosseini (2008) reported similar results. In addition, Nouri and Nasab (2011) concluded that the AFI system generally increases sugar cane yield and field WUE. Clearly, WP depends on total applied water. This provides a useful guide to retrospectively assess the irrigation strategy. This finding agrees with results obtained by Ibrahim and Emara (2010), who reported that an adverse relationship was found between the amount of applied irrigation water and WP for both beet root and sugar yield.

\section{Benefit-cost ratio (BCR) and net return (NR)}

The benefit-cost ratio (BCR) and net return (NR) were significantly affected by the irrigation treatments (Table 4). Maximum BCR was 1.63 and 1.76 obtained for $\mathrm{AFI}_{7}$, followed by 1.37 and 1.48 for EFI, whereas minimum $\mathrm{BCR}$ was 1.34 and 1.46 observed for $\mathrm{AFI}_{14}$ in the first and second seasons, respectively. Maximum NR was 1669 and 1765 US $\$$ ha $^{-1}$ obtained for $\mathrm{AFI}_{7}$ as compared with EFI

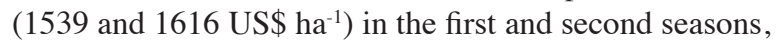
respectively. The other treatment, $\mathrm{AFI}_{14}$, had the lowest

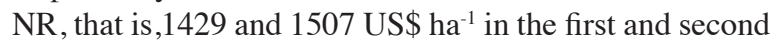
seasons, respectively. These results indicated that if water is available with no high cost and excess water delivery to the field does not require any additional expense, the $\mathrm{AFI}_{7}$ treatment is essentially the best choice under the conditions of the study area.

The use of appropriate irrigation intervals for better growth and higher yield could be economically attractive to reduce drought stress conditions in areas with limited water (Khan et al., 2005). Among different irrigation treatments, alternate furrow irrigation at 7-d intervals $\left(\mathrm{AFI}_{7}\right)$ had the maximum return and the highest BCR in both seasons. These results may be due to improved $\mathrm{WP}$ and $\mathrm{WUE}_{\text {crop }}$ for $\mathrm{AFI}_{7}$, which leads to high yield. This finding is similar to results obtained by Igbadun et al. (2006); Nelson and Al-Kaisi (2011). On the other hand, Ghasemi and Sepaskhah (2003) showed that BCR for the AFI method of 10-d intervals did not differ much from BCR of common furrow irrigation with 10-d intervals; these were even higher in the Bajgah area. Moreover, they indicated that with a higher water price the farmer should increase farm irrigation application efficiency to avoid economic losses.

Table 4. Benefit-cost ratio (BCR) and net return (NR) associated with the adopted irrigation treatments.

\begin{tabular}{|c|c|c|c|c|c|c|c|c|}
\hline Treatments & $\begin{array}{l}\text { Applied } \\
\text { water }\end{array}$ & $\begin{array}{c}\text { Cost of } \\
\text { applied water }\end{array}$ & $\begin{array}{l}\text { Operating } \\
\text { costs }\end{array}$ & $\begin{array}{r}\text { Total } \\
\text { costs }^{@}\end{array}$ & $\begin{array}{l}\text { Grain } \\
\text { yield }\end{array}$ & $\begin{array}{c}\text { Gross } \\
\text { revenue }\end{array}$ & NR & $\mathrm{BCR}^{A}$ \\
\hline \multicolumn{8}{|l|}{ Season, 2010} & \\
\hline EFI & 5291 & 225 & 425 & 650 & 5660 & 1539 & $889 b$ & $1.37 \mathrm{~b}$ \\
\hline $\mathrm{AFI}_{7}$ & 4949 & 210 & 425 & 635 & 6140 & 1669 & $1034 \mathrm{a}$ & $1.63 \mathrm{a}$ \\
\hline $\mathrm{AFI}_{14}$ & 4376 & 186 & 425 & 611 & 5250 & 1429 & $818 \mathrm{c}$ & $1.34 \mathrm{c}$ \\
\hline $\mathrm{LSD}_{0.05}$ & - & - & - & - & - & - & 38 & 0.023 \\
\hline \multicolumn{9}{|l|}{ Season, 2011} \\
\hline EFI & 5339 & 227 & 425 & 652 & 5940 & 1616 & $964 b$ & $1.48 \mathrm{~b}$ \\
\hline $\mathrm{AFI}_{7}$ & 5039 & 214 & 425 & 639 & 6490 & 1765 & $1126 \mathrm{a}$ & $1.76 \mathrm{a}$ \\
\hline $\mathrm{AFI}_{14}$ & 4414 & 188 & 425 & 613 & 5540 & 1507 & $894 b$ & $1.46 \mathrm{~b}$ \\
\hline $\operatorname{LSD}_{0.05}$ & - & - & - & - & - & - & 77 & 0.124 \\
\hline
\end{tabular}

EFI: Every-furrow irrigation, $\mathrm{AFI}_{14}$ : alternate furrow irrigation with 14-d intervals, and $\mathrm{AFI}_{7}$ : alternate furrow irrigation with 7-d intervals, $\mathrm{LSD}$ : least significant difference at 0.05 significance level.

${ }^{\text {"BCR }}$ with the same letter is not significantly different $(\mathrm{P}<0.05)$.

${ }^{\circledR}$ Total costs $=$ Operating costs + Cost of applied water.

Currency exchange: 1 EGP (Egyptian pound) $\approx$ US\$0.17 in 2011. 


\section{CONCLUSIONS}

Alternate-furrow irrigation with appropriate irrigation intervals (7-d) can be used as an efficient method for corn production in arid areas where production depends heavily on irrigation. It could be concluded that the $\mathrm{AFI}_{7}$ treatment controlled stress irrigation without the risk of reduced grain yield. Moreover, it increased the benefitcost ratio (BCR), net return (NR), and saved irrigation water. The preference between $\mathrm{AFI}_{7}$ treatment and other treatments depends on the value of water in relation to crop returns. Therefore, it is recommended that if the cost of available water is not high and excess water delivery to the field does not require any additional expense, then the alternate furrow irrigation with 7-d intervals will essentially be the best choice under the conditions of the study area.

\section{ACKNOWLEDGEMENTS}

The author acknowledges Prof. Dr. Mahmoud M. Ibrahim, Soil and Water Department, Faculty of Agriculture, Tanta University for his valuable comments when reviewing and improving the earlier versions of this paper. The author also thanks Mr. Mohamed Ali Hamada, Soil and Water Department, Faculty of Agriculture, Tanta University for his permission to use his private farm to conduct the present study.

\section{LITERATURE CITED}

Abdel-Maksoud, H.H., Sanaa A. Othman, and A.Y. El-Tawil. 2002. Improving water and $\mathrm{N}$-use utilization for field crops via alternate furrow irrigation technique 1-Maize crop. Mansoura University Journal of Agricultural Sciences Mansoura University 27:87618769.

Ali, M.H., M.R. Hoque, A.A. Hassan, and A. Khair. 2007. Effects of deficit irrigation on yield, water productivity and economic returns of wheat. Agricultural Water Management 92:151-161.

Carter, M.R., and E.G. Gregorich. 2008. Soil sampling and methods of analysis. $2^{\text {nd }}$ ed. CRC Press, Boca Raton, Florida, USA.

El Baroudy, A.A. 2011. Monitoring land degradation using remote sensing and GIS techniques in an area of the middle Nile Delta. Egypt. Catena 87(2):201-208.

El-Beltagy, A.T., and A.F. Abo-Hadeed. 2008. The main pillars of the National Program for maximizing the water-use efficiency in the old land. 30 p. The Research and Development Council. Ministry of Agriculture and Land Reclamation (MOALR), Giza, Egypt (in Arabic).

El-Sharkawy, A.F., A.Kh. Mostafa, and H.H. Abdel Maksoad. 2006. Effect of alternate furrow irrigation and transplanting distance on water utilisation efficiency for onion crop. Misr Journal of Agricultural Engineering 23:137-150.

Ghasemi, M.M., and A.R. Sepaskhah. 2003. Economic evaluation of every-other furrow irrigation for sorghum with real and subsidized irrigation water prices. Journal of Science and Technology of Agriculture and Natural Resources 7(2):1-11. (Abstract)

Graterol, Y.E., D.E. Eisenhauer, and R.W. Elmore. 1993. Alternate furrow irrigation for soybean production. Agricultural Water Management 24:133-145.

Ibrahim, M.A.M., and T.K. Emara. 2010. Water saving under alternative furrows surface irrigation in clay soils of north Nile delta. Fourteenth International Water Technology Conference (IWTC), Cairo. 21-23 March. Water Technology Association (WTA), Cairo, Egypt.

Igbadun, H.E., H.F. Mahoo, A.K.P.R. Tarimo, and B.A. Salim. 2006 Crop water productivity of an irrigated Maize crop in Mkoji subcatchment of the Great Ruaha River Basin, Tanzania. Agricultural Water Management 85:141-150.

James, L.G. 1988. Principles of farm irrigation system design. 410 p. John Wiley \& Sons, New York, USA.

Kashiani, P., G. Saleh, M. Osman, and D. Habibi. 2011. Sweet corn yield response to alternate furrow irrigation methods under different planting densities in a semi-arid climatic condition. African Journal of Agricultural Research 6:1032-1040.

Khan, M.H., T.H. Chattha, and N. Saleem. 2005. Influence of different irrigation intervals on growth and yield of bell pepper (Capsicum annuum Grossum Group). Journal of Agricultural Biology Science 1:125-128.

Li, A., E. Eneji, L. Duan, S. Inanaga, and Z. Li. 2005. Saving irrigation water for winter wheat with phosphorus application in the north China plain. Journal of Plant Nutrition 28:2001-2010.

Li, F., J. Liang, S. Kang, and J. Zhang. 2007. Benefits of alternate partial root-zone irrigation on growth, water and nitrogen use efficiencies modified by fertilization and soil water status in maize. Plant and Soil 295(1-2):279-291.

Nasri, M., M. Khalatbari, and H.A. Farahani. 2010. The effect of alternate furrow irrigation under different nutritional element supplies on some agronomic traits and seed qualitative parameters in corn (Zea mays L.) Journal of Cereals and Oilseed 1(2):17-23.

Nelson, D.J., and M.M. Al-Kaisi. 2011. Agronomic and economic evaluation of various furrow irrigation strategies for corn production under limited water supply. Journal of Soil Water Conservation 66(2):114-120.

Nouri, M., and S.B. Nasab. 2011. Study of effect of alternate furrow irrigation in sugarcane (Var CP69-1062) at different growth stages on quality and quantity of yield. p. 287-291. ICID $21^{\text {st }}$ International Congress on Irrigation and Drainage (ICID), Tehran, Iran. 15-23 October. International Commission of Irrigation and Drainage (ICI), New Delhi, India.

Rafiee, M., and G. Shakarami. 2010. Water use efficiency of corn as affected by every other furrow irrigation and planting density. World Applied Science Journal 11:826-829.

Sepaskhah, A.R., and M. Ghasemi. 2008. Every-other- furrow irrigation with different intervals for sorghum. Pakistan Journal of Biology Science 11:1234-1239.

Sepaskhah, A.R., and S.N. Hosseini. 2008. Effects of alternate furrow irrigation and nitrogen application rates on yield and water- and nitrogen-use efficiency of winter wheat (Triticum aestivum L.) Plant Production Science 11:250-259.

Sepaskhah, A.R., and M.H. Khajehabdollahi. 2005. Alternate furrow irrigation with different irrigation intervals for maize (Zea mays L.) Plant Production Science 8:592-600.

Sepaskhah, A.R., and A.R. Parand. 2006. Effects of alternate furrow irrigation with supplemental every-furrow irrigation at different growth stages on the yield of maize (Zea mays L.) Plant Production Science 9:415-421.

Shayannejad, M., and A. Moharreri. 2009. Effect of every-other furrow irrigation on water use efficiency, starch and protein contents of potato. Journal of Agricultural Science 1(2):107-112.

Tavakoli, A.R., and T.Y. Oweis. 2004. The role of supplemental irrigation and nitrogen in producing bread wheat in the highlands of Iran. Agricultural Water Management 65:225-236.

USDA. 2011. Grain: World markets and trade. Foreign Agriculture Service, Circular Series FG 09-11. Foreign Agricultural Service, United States Department of Agriculture. Available at http://www. fas.usda.gov/psdonline/circulars/grain.pdf (accessed 9 October 2011).

Webber, H.A., C.A. Madramootoo, M. Bourgault, M.G. Horst, G. Stulina, and D.L. Smith. 2006. Water use efficiency of common bean and green gram grown using alternate furrow and deficit irrigation. Agricultural Water Management 86:259-268. 